\title{
The Effect of Glucomannan Inclusion Derived from Porang Tuber Extract (Amorphophallus oncophyllus) on Dietary Protein Utilization in Broiler Chicken
}

\author{
Khanifah $^{1}$, Suthama $\mathrm{N}^{2}$, Wahyuni $\mathrm{HI}^{2}$ \\ ${ }^{I}$ Student of Faculty of Animal Science of the University of Diponegoro, Semarang \\ ${ }^{2}$ Staf Lecturer of Faculty of Animal and Agricultural Science of Universitas Diponegoro, Semarang \\ E-mail: khanifah89@gmail.com
}

(received 12-02-2018; revised 28-05-2018; accepted 30-05-2018)

\begin{abstract}
ABSTRAK
Khanifah, Suthama N, Wahyuni HI. 2018. Pemanfaatan protein ransum pada ayam broiler akibat penambahan glukonaman dari ekstrak umbi porang (Amporphopallus onchophyllus). JITV 23(2): 77-81. DOI: http://dx.doi.org/10.14334/jitv.v23i2.1834

Penelitian bertujuan untuk mengkaji pengaruh penambahan glukomanan dari ekstrak umbi porang (GPTE) terhadap kemampuan produktivitas ayam broiler. Ternak yang digunakan adalah ayam broiler strain New Lohmann umur 1 hari sebanyak

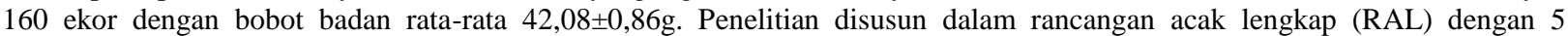
perlakuan dan 4 ulangan, masing-masing ulangan dengan 8 ekor ayam. Perlakuan yang diberikan yaitu $\mathrm{T} 0=$ ransum basal, $\mathrm{T} 1=$ $\mathrm{T} 0+0,05 \%$ GPTE,T $2=\mathrm{T} 0+0,10 \%$ GPTE, T3 $=\mathrm{T} 0+0,15 \%$ GPTE dan T $4=\mathrm{T} 0+0,20 \%$ GPTE. Parameter yang diamati meliputi koefisien cerna protein, retensi nitrogen, massa kalsium daging, dan massa protein daging. Hasil penelitian menunjukkan bahwa penambahan GPTE nyata $(\mathrm{P}<0,05)$ meningkatkan koefisien cerna protein, massa kalsium daging dan massa protein daging, tetapi tidak mempengaruhi retensi nitrogen. Koefisien cerna protein dan massa kalsium daging tertinggi pada penambahan $0,2 \%$ GPTE (T4) tetapi tidak berbeda dengan T3, sedangkan massa protein daging tertinggi pada T2 tetapi tidak berbeda dengan T3 dan T4. Kesimpulan penelitian yaitu penambahan GPTE 0,15\% (T3) pada ransum ayam broiler dapat meningkatkan koefisien cerna protein, massa kalsium dan protein daging, serta pertambahan bobot badan harian, meskipun retensi nitrogen sama.
\end{abstract}

Kata Kunci: Glukomanan, Koefisien Cerna Protein, Retensi Nitrogen, Massa Kalsium, Protein Daging, Broiler

\section{ABSTRACT}

Khanifah, Suthama N, Wahyuni HI. 2018. The effect of glucomannan inclusion derived from porang tuber extract (Amorphophallus oncophyllus) on dietary protein utilization in broiler chicken. JITV 23(2): 77-81. DOI: http://dx.doi.org/10.14334/jitv.v23i2.1834

The aim of this study was to evaluate the effect of glucomannan inclusion derived from porang (Amorphophallus oncophyllus) tuber extract (GPTE) on production performance of broiler chicken. A total of 160 one day old of New Lohmann broiler chickens with an average initial body weight of $42.08 \pm 0.86 \mathrm{~g}$ were used in this study. The study was arranged in a completely randomized design with 5 treatments and 4 replications $(8$ birds each). The treatments applied were T0 $=$ basal ration, $\mathrm{T} 1=\mathrm{T} 0+0.05 \%$ GPTE, $\mathrm{T} 2=\mathrm{T} 0+0.10 \% \mathrm{GPTE}, \mathrm{T} 3=\mathrm{T} 0+0.15 \% \mathrm{GPTE}$ and $\mathrm{T} 4=\mathrm{T} 0+0.20 \%$ GPTE. The parameters observed were protein digestibility, nitrogen retention, meat calcium and protein mass. The results showed that dietary addition of GPTE significantly $(\mathrm{P}<0.05)$ increased the coefficient of protein digestibility, meat calcium and protein mass, but had no effect on nitrogen retention. The highest protein digestibility and meat calcium mass were shown in T4, but they were not significantly different from those in $\mathrm{T} 3$, and $\mathrm{T} 2$ for protein digestibility. While the highest meat protein mass was in $\mathrm{T} 2$ but it was not different with than in T3 and T4. The conclusion of the study is that dietary supplementation of glucomannan derived from porang tuber extract in broiler up to $0.15 \%$ (T3) increases protein digestibility, meat calcium and protein mass, and daily weight gain with similar nitrogen retention.

Key Words: Glucomannan, Protein Digestibility, Nitrogen Retention, Meat Calcium, Protein Mass, Broiler

\section{INTRODUCTION}

Diet is a crucial determinant factor in poultry productivity maintenance, including broiler chickens. Since diet is the largest cost of broiler chicken production, an effective effort to improve the diet utilization and production efficiency is needed. Feeding non-antibiotic feed additive is one effort that can be performed to avoid the remaining residue in the product. Haryati et al. (2010) reported that the impact of the continuous and inappropriate use of antibiotics led to bacterial resistance to the animal and consumers. Prebiotic is one possible health-friendly nonantibiotic 
feed additives that can be used in poultry feed and feeding.

Prebiotics are additives substances that could not be digested by the gastrointestinal tract, but were selectively fermented by lactic acid bacteria thereby increasing the activity of beneficial bacteria in the gut (Daud et al. 2007). Prebiotic compounds often used in poultry was a non-digestible oligosaccharide, including fructooligosaccharide, manan-oligosaccharide, and xylooligosaccharide. The prebiotics used in this study were glucomannan derived from porang tuber extract.

Glucomannan from porang tuber is an oligosaccharide group. An oligosaccharide is a type of prebiotic that could be applied to poultry (Haryati et al. 2010). Prebiotics oligosaccharide were difficult to be digested but it could be fermented by beneficial bacteria present in the gastrointestinal tract (Haryati et al. 2010). Glucomannan from the porang tuber is potentially used as a source of prebiotics. Glucomannan could be categorized as a source of prebiotic oligosaccharides (Zhang et al. 2014). The porangtuber as a source of oligosaccharide prebiotics contained glucomannan more than $60 \%$ (Rahayu 2013).

Addition glucomannan as prebiotic would stimulate the development of lactid acid bacteria. Additive oligosaccharide, including inulin, can be fermented by intestinal bacteria, especially lactic acid bacteria, to produce short-chain fatty acid such as acetate, butyric and propionate that inducing low intestinal $\mathrm{pH}$ (Fanani et al. 2016). Low $\mathrm{pH}$ conditions suppressed the growth of pathogenic bacteria but increasing the beneficial bacteria which leads to the better microflora balanced and improved the digestive tract health. The improvement of digestive tract health indirectly improves the digestion and absorption of nutrients, especially protein. Digestion and protein absorption increased meat calcium and protein mass (Wijayanti 2016).

The aim of this research was to evaluate the effect of glucomannan inclusion fromporangtuberon productive ability of broiler in terms of protein digestibility coefficient, nitrogen retention, meatcalcium mass, and meat protein mass. This researchcan be used as a basis of scientific informationfor the farmer community concerning the beneficial effect of glucomannan from porang tuber extract as prebiotic to increase broiler productivity.

\section{MATERIALS AND METHODS}

One day old New Lohman broiler chickens with initial body weight of $42.08 \pm 0.86 \mathrm{~g}$ were used in this study. This study was arranged in a completely randomized design with 5 treatments and 4 replications, 8 chicks per replication. The treatments were $\mathrm{T} 0=$ basal diet, $\mathrm{T} 1=\mathrm{T} 0+0.05 \%$ glucomannan from porang tuber extract $($ GPTE $), \mathrm{T} 2=\mathrm{T} 0+0.10 \%$ GPTE, $\mathrm{T} 3=\mathrm{T} 0+$ $0.15 \%$ GPTE and T4 $=$ T0 $+0.20 \%$ GPTE. The GPTE addition was in percentage of total diet basis. Composition and nutritional content of experimental feed are presented in Table 1 .

Table 1. Composition and nutrient content of the experimental diet

\begin{tabular}{lc}
\hline \hline Ingredients & Composition \\
\hline Yellow corn, (\%) & 54.00 \\
Rice bran, (\%) & 14.20 \\
Soybean meal, (\%) & 18.00 \\
Meat bone meal, (\%) & 5.75 \\
Poultry meat meal, (\%) & 6.75 \\
Dicalcium phospate, (\%) & 0.50 \\
L-Lysine, (\%) & 0.10 \\
DL-Methionine, (\%) & 0.20 \\
Calcium carbonate, (\%) & 0.25 \\
Premix, (\%) & 0.25 \\
\hline Total & 100.00 \\
\hline
\end{tabular}

Nutrient content ${ }^{1)}$

Metabolisable energy $(\mathrm{Kcal} / \mathrm{kg})^{2)}$ 2965.69

Crude protein, $(\%)$

Ether extract (\%)

Crude fiber $(\%)$

Methionine $^{3)}(\%)$

0.55

Lysine $^{3)}(\%)$

$\mathrm{Ca}(\%)$

$\mathrm{P}(\%)$

0.71

${ }^{1}$ Analyzed at the Laboratory of Animal Nutrition and Feed Science, Faculty of Animal and Agricultural Sciences, Diponegoro University ${ }^{2}$ Calculated based on Balton formula (Siswohardjono 1982) cyted by Wahyuni et al. (2008)

${ }^{3}$ Calculated based on NRC (1994)

This research was started with the preparation of glucomannan extract, diet and cage and its equipment. Glucomannan extract was made from porang tuber according to the modified method of Tatirat \& Charoenrein (2011). The chickens were offered dietary treatments since one day old until 35 days old (slaughtered age). The birds from 1 to 14 days old were kept in litter floored-cage, and they were moved and kept in the individual cage (battery) there after. Vaccinations were provided onday 4 for Newcastle 
Disease (ND), on day14 for gumboro, and on day 20 for ND2.

The GPTE was based on the treatment levelswas mixed with a small portion of feed and offered in the morning to ensure the amount was completely consumed. The feed without GPTE for daily requirement and drinking water were provided ad libitum.

Protein digestibility coefficient was measured using total collection method combined with indicator according to Indreswari et al. (2009). Excreta was collected from 1 chicken per replication on day 31,32 , 33 and 34. Crude protein (CP) consumption was obtained from the amount of feed consumed during total excreta collection was performed. The protein digestibility coefficient was calculated using the formula of McDonald et al. (2002), namely:

$$
\mathrm{PDC}=\frac{\mathrm{CCP}-\mathrm{CPE}}{\mathrm{CCP}} \times 100 \%
$$

$\mathrm{PDC}=$ Protein digestibility coefficient

$\mathrm{CCP}=$ Consumption of Crude Protein

$\mathrm{CPE}=$ Crude Protein of Excreta

Nitrogen retention was measured based on the difference of the amout of nitrogen consumed and fecal nitrogen.

Calcium and protein mass was measured from meat samples. Meat samples of approximately $100 \mathrm{~g}$ were obtained from each part of carcassof one birdin each replication. The samples were mixed and finely ground and then taken as much as $20 \mathrm{~g}$ for the analysis of calcium, protein and moisture contents. The protein and calcium mass of meat was calculated based on Suthama (2003) as follows:

$\begin{array}{lccc}\begin{array}{l}\text { Meat Calcium } \\ \text { Mass }(\mathrm{g})=\end{array} & \begin{array}{c}\text { Meat Calcium } \\ \text { Content }(\%)\end{array} & \text { x } & \begin{array}{c}\text { Meat Weight } \\ (\mathrm{g})\end{array} \\ \begin{array}{l}\text { Meat Protein } \\ \text { Mass }(\mathrm{g})=\end{array} & \begin{array}{c}\text { Meat Protein } \\ \text { Content }(\%)\end{array} & \text { x } & \begin{array}{c}\text { Meat Weight } \\ (\mathrm{g}) .\end{array}\end{array}$

Data were subjected to analysis of variance with $\mathrm{F}$ test to determine the effect of treatment. When the treatment indicated significant effect, it was continued to Duncan multiple range test at 5\% probability level.

\section{RESULTS AND DISCUSSION}

The addition of GPTE as a prebiotic source in broiler diet on protein consumption, protein excreta, protein digestibility coefficient and nitrogen retention are presented in Table 2. Dietary addition of GPTE indicated significant effect only on protein digestibility coefficient. Protein digestibility coefficient of T0 treatment was significantly $(\mathrm{P}<0.05)$ lower that that of other treatments, and that of $\mathrm{T} 1$ was also lower as compared to that of $\mathrm{T} 4$ but no diferences among other treatments. The addition of GPTE at $0.20 \%$ (T4) increased protein digestibility to the highest value even though no difference was found compared to T2 and T3. Feeding GPTE in broiler as compared to control diet improved protein digestibility coefficient. Protein digestibility coefficient was closely related to digestive tract health due to the addition of prebiotic glucomannan (GPTE). The increase in protein digestion coefficient was assumed that GPTE played a role as a source of "food or nutrient" that could be exploited by the beneficial endogenous bacteria in the digestive tract.

Better digestive tract health brought about the increased protein digestibility coefficient Muhammad et al. (2015) stated that the addition of prebiotics could balance the microflora in the gastrointestinal tract by increasing beneficial bacteria counts, and decreasing pathogenic bacteria population. This gastrointestial condition provided an impact on the increase in nutrient digestibility such as protein digestibility coefficient. Guilloteau et al. (2010) reported that the addition of prebiotics in chickens can increase short-chain fatty acids leading to the decrease in $\mathrm{pH}$ of the gastrointestinal tract and then increasing the activity of beneficial bacteria. Similarly, feeding probiotic inulin in crossbred local chicken increased lactic acid bacteria and decreased the population of Escherichia coli (Krismiyanto et al. 2015), thereby positively affecting the health of the gastrointestinal tract leading to the increase in protein digestibility (Fanani et al. 2016). Research result of Muhammad et al. (2015) also showed that the addition of prebiotic increased protein digestibility.

The different pattern was found with nitrogen retention (Table 2) that there was no significant effect caused by the addition of GPTE even though protein digestibility coefficient increased. Nitrogen retention was not significantly different due to the same dietary protein content and nitrogen consumption. The present result was in accordance with the report of Primacitra et al. (2014). Ma'rifah et al. (2013) also mentioned that nitrogen retention was influenced by nitrogen consumption, because nitrogen retention was calculated based on the value of nitrogen consumption. Wijayanti (2016) also supported the present result that the dietary addition of prebiotic soybean oligosaccharide (SOS) in broiler significantly increased protein digestibility coefficient, but nitrogen retention was the same. Nitrogen retention was not statistically different, but the addition of GPTE tended to increase its value numerically. This phenomenon suggested that dietary inclusion effect of GPTE would be significant when added at higher level. However, this condition indicated that the addition of GPTE improved the efficiency of 
protein utilization since the higher meat protein mass can be resulted (Table 3) although with the same nitrogen retention (Table 2).

Dietary additional effect of GPTE as a prebiotic source on meat protein and calcium mass is presented in Table 3 . Both parameters were significantly affected by dietary inclusion of GPTE.

Meat protein mass in $\mathrm{T} 0$ and $\mathrm{T} 1$ treatments indicated the same values, and both were significantly $(\mathrm{P}<0.05)$ lower than that in $\mathrm{T} 2, \mathrm{~T} 3$ and $\mathrm{T} 4$, but there was no different among that in $\mathrm{T} 2$, T3 and T4. This was in accordance with the increase in protein digestibility coefficient. The increased protein digestibility coefficient was assumed to be due to a higher increase in protein intake even though nitrogen retention was the same. Therefore, the increased meat protein mass was an evidence of the improvement rate of muscle protein synthesis due to feeding effect of GPTE up to $0.2 \%$. Wijayanti (2016) reported that supplementation of prebiotic soybean oligosaccharide (SOS) was able to improve protein digestibility coefficient that brought about higher protein supply as a substrate for the increase in meat protein mass. The higher meat protein mass indicates the better protein deposition due to utilization efficiency of dietary protein for tissue synthesis.

Similar value of meat calcium mass was found among T0, T1, and T2 treatments and they were significantly $(\mathrm{P}<0.05)$ lower than that in $\mathrm{T} 3$ and $\mathrm{T} 4$, but there was no difference between $\mathrm{T} 3$ and $\mathrm{T} 4$ treatments (Table 3). Meat calcium mass showed the same pattern with meat protein mass. The calcium mass of meat in $\mathrm{T} 3$ and T4 increased along with the increase in protein digestibility coefficient. The increase in calcium mass of meat due to the addition of GPTE was in accordance with protein digestibility coefficient and meat protein mass. The increase in protein digestibility coefficient in this study was assumed to play an important role in binding calcium called calcium binding protein $(\mathrm{CaBP})$, thereby increasing the absorption of calcium which causes the increase in meat calcium mass. This was in accordance with the result reported by Syafitri et al. (2015) that the addition of beluntas leaf extract as feed additive can increased meat calcium mass supported by the improved protein digestibility coefficient and higher calcium retention bringing about the high calcium deposition in the meat. Fanani et al. (2016) stated that feeding prebiotic inulin improved protein digestibility coefficient that closely related to the absorption of calcium. As it has been previously discussed that calcium was absorbed together with a protein called $\mathrm{CaBP}$, thus, it can be assumed that increasing protein digestibility coefficient followed by increased calcium absorption resulting in the increase in meat calcium mass.

The increased meat protein mass was closely related to the improved body weight gain. This relationship was indicated by the pattern between meat protein mass and body weight gain was almost the same. Body weight gain of T2, T3 and T4 treatments were higher than that of T0 and T1 (Table 3). However, when GPTE was added at the level of $0.15 \%$ (T3) resulted high growth and better meat product similar to those of T4 $(0.20 \%$ GPTE), but T3 more efficient because lower amount of porang tuber extract was used. Output

Table 2. Protein digestibility coefficient and nitrogen retention in broiler chicken fed diet with addition of glucomannan from porang tuber extract (GPTE)

\begin{tabular}{lccccc}
\hline \hline \multirow{2}{*}{ Parameter } & \multicolumn{5}{c}{ Level GPTE (\%) } \\
\cline { 2 - 6 } & $\mathrm{T} 0(0)$ & $\mathrm{T} 1(0.05)$ & $\mathrm{T} 2(0.10)$ & $\mathrm{T} 3(0.15)$ & $\mathrm{T} 4(0.20)$ \\
\hline Protein consumption (g/bird/day) & 28.04 & 27.61 & 28.77 & 27.90 & 27.53 \\
Protein in excreta (g) & 6.55 & 5.49 & 5.24 & 4.91 & 4.64 \\
Coefficient of protein digestibility (\%) & $76.70^{\mathrm{c}}$ & $80.14^{\mathrm{b}}$ & $81.78^{\mathrm{ab}}$ & $82.28^{\mathrm{ab}}$ & $83.09^{\mathrm{a}}$ \\
Nitrogen retention (g/bird/day) & 3.44 & 3.54 & 3.76 & 3.68 & 3.66 \\
\hline
\end{tabular}

${ }^{\mathrm{a}-\mathrm{c}}$ Different superscript at the same raw shows significantly difference $(\mathrm{P}<0.05)$

Table 3. Meat protein and calcium mass of broiler fed diet with addition of glucomannan from porang tuber extract (GPTE)

\begin{tabular}{|c|c|c|c|c|c|}
\hline \multirow{2}{*}{ Parameter } & \multicolumn{5}{|c|}{ Level GPTE (\%) } \\
\hline & T0 (0) & $\mathrm{T} 1(0.05)$ & $\mathrm{T} 2(0.10)$ & $\mathrm{T} 3(0.15)$ & $\mathrm{T} 4(0.20)$ \\
\hline Meat protein mass (g/bird)) & $150.39^{\mathrm{b}}$ & $161.98^{b}$ & $187.45^{\mathrm{a}}$ & $181.62^{\mathrm{a}}$ & $182.10^{\mathrm{a}}$ \\
\hline Meat calcium mass (mg/bird) & $59.51^{b}$ & $64.20^{\mathrm{b}}$ & $68.18^{\mathrm{b}}$ & $84.32^{\mathrm{a}}$ & $85.28^{\mathrm{a}}$ \\
\hline Body weight gain (g/bird/day) & $39.59^{b}$ & $40.50^{\mathrm{ab}}$ & $42.30^{\mathrm{a}}$ & $41.60^{\mathrm{a}}$ & $42.13^{\mathrm{a}}$ \\
\hline
\end{tabular}

${ }^{a-b}$ Different superscript at the same raw shows significantly difference $(\mathrm{P}<0.05)$ 
specification produced in T3 treatment can be categorized as better meat quality due to its rich in calcium and protein deposition with high body weight. The determinant of meat quality was chemical compositions including protein and calcium (Dewi 2013). Thus, T3 resulted better meat quality with high body weight and more efficient as compared to $\mathrm{T} 4$.

\section{CONCLUSION}

Inclusion of glucomannan derived from porang tuber extract (GPTE) in broiler chicken diet at $0.15 \%$ (T3) can improve protein digestibility, and produce better and more efficient meat quality based on calcium and protein mass and daily body weight gain.

\section{REFERENCES}

Daud M, Piliang WG, Kompiang IP. 2007. Persentase dan kualitas karkas ayam pedaging yang diberi probiotik dan prebiotik dalam ransum. Indones $\mathbf{J}$ Anim Vet Sci. 12:168-174.

Dewi SHC. 2013. Kualitas kimia daging ayam kampung dengan ransum berbasis konsentrat broiler. J AgriSains. 4:42-49.

Fanani AF, Suthama N, Sukamto B. 2016. Efek penambahan umbi bunga dahlia sebagai sumber inulin terhadap koefisien cerna protein dan produktivitas ayam lokal persilangan. J Kedokteran Hewan. 10:58-62.

Guilloteau P, Martin L, Eeckhaut V, Ducatelle R, Zabielski R, Immerseel FV. 2010. From the gut to the peripheral tissues: The multiple effects of butyrate. Nutr Res Rev. 23:366-384.

Haryati T, Suprijati K, Susana IWR. 2010. Senyawa oligosakarida dari bungkil kedelai dan ubi jalar sebagai prebiotik untuk ternak. Prasetyo LH, Natalia L, Iskandar S, Puastuti W, Herawati T, Nurhayati, Anggraeni A, Damayanti R, Darmayanti NLPI, Estuningsih SE, editors. Prosiding Seminar Nasional Teknologi Peternakan dan Veteriner. Bogor (Indones): Indonesian Center for Animal Research and Development. p. 511-518.

Indreswari R, Wahyuni HI, Suthama N. 2009. Pemanfaatan kalsium untuk pembentukan cangkang telur akibat perbedaan porsi pemberian ransum pagi dan siang pada ayam petelur. J Indones Trop Anim Agric. 34:134-138.

Krismiyanto L, Suthama N, Wahyuni HI. 2015. Keberadaan bakteri dan perkembangan caecum akibat penambahan inulin dari umbi dahlia (Dahlia variabilis) pada ayam kampung persilangan periode starter. J Ilmu-ilmu Peternakan. 24:54-60.

Ma'rifah B, Atmomarsono U, Suthama N. 2013. Nitrogen retention and productive performance of crossbred native chicken due to feeding effect of kayambang (Salvinia molesta). IJSE. 5:19-24.

McDonald P, Edward RA, Greenhalgh JFG, Morgan CA. 2002. Animal Nutrition. 6th ed. Gosport.

Muhammad S, Fawwad A, Mansoor J, Shahbaz A. 2015. Effect of $\beta$-Mannanase on broilers performance. J Agric Sci. 5:237-246.

[NRC] Nutrient Requirement Council. 1994. Nutrient Requirement of Poultry. Washington DC (USA): National Academic Press.

Primacitra DY, Sjofjan O, Natsir MH. 2014. Pengaruh penambahan probiotik (Lactobacillus sp.) dalam pakan terhadap energi metabolis, kecernaan protein dan aktivitas enzim burung puyuh. J Ternak Tropika. 15:7479.

Rahayu LH. 2013. Peningkatan kadar glukomanan dari tepung porang (Amorphophallus oncophyllus) melalui metode pencucian menggunakan larutan isopropil alkohol (IPA) berbantu ultrasonic [Thesis]. [Semarang (Indones)]: Universitas Diponegoro.

Syafitri YE, Yunianto VD, Suthama N. 2015. Pemberian ekstrak daun beluntas (Pluchea indica Less) dan klorin terhadap massa kalsium dan massa protein daging pada ayam broiler. J Anim Agric. 4:155-164.

Suthama N. 2003. Metabolisme protein pada ayam lokal periode pertumbuhan diberi ransum memakai dedak padi fermentasi. J Pengembangan Peternakan Tropis. Special Edition:44-48.

Tatirat O, Charoenrein S. 2011. Physicochemical properties of konjac glucommanan extracted from konjac flour by a simple centrifugation process. Food Sci Technol. 44:2059-2063.

Wahyuni HI, Pujaningsih RI, Sayekti PA. 2008. Kajian nilai energi metabolis biji sorghum melalui teknologi sangrai pada ayam petelur periode afkir. Agripet. 8:25-30.

Wijayanti DA. 2016. Pemanfaatan Soybean oligosakarida dari ekstrak bungkil dan kulit kedelai sebagai prebiotik terhadap koefisien cerna protein dan produktivitas ayam broiler (Thesis). [Semarang (Indones)]: Universitas Diponegoro.

Zhang C, Chen J, Yang F. 2014, Konjac glucomannan, a promising polysaccharide for OCDDS. Carbohydrate Polymers. 104:175-181. 